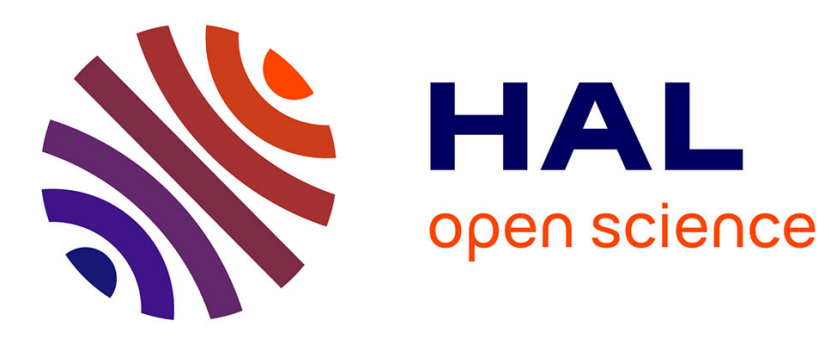

\title{
Overall business climate and its impact on environmental sustainability: analyzing evidence from ASEAN countries
}

\author{
Meqbel Mishary Aliedan
}

\section{- To cite this version:}

Meqbel Mishary Aliedan. Overall business climate and its impact on environmental sustainability: analyzing evidence from ASEAN countries. Journal of Security and Sustainability Issues, 2020, 10 (October), pp.291 - 302. 10.9770/jssi.2020.10.oct(22) . hal-03121009

\author{
HAL Id: hal-03121009 \\ https://hal.science/hal-03121009
}

Submitted on 26 Jan 2021

HAL is a multi-disciplinary open access archive for the deposit and dissemination of scientific research documents, whether they are published or not. The documents may come from teaching and research institutions in France or abroad, or from public or private research centers.
L'archive ouverte pluridisciplinaire HAL, est destinée au dépôt et à la diffusion de documents scientifiques de niveau recherche, publiés ou non, émanant des établissements d'enseignement et de recherche français ou étrangers, des laboratoires publics ou privés. 
JOURNAL OF SECURITY AND SUSTAINABILITY ISSUES

ISSN 2029-7017/ISSN 2029-7025 (online)

2020 Volume 10 Number (October)

http://doi.org/10.9770/jssi.2020.10.Oct(22)

Scopus

OVERALL BUSINESS CLIMATE AND ITS IMPACT ON ENVIRONMENTAL SUSTAINABILITY: ANALYZING EVIDENCE FROM ASEAN COUNTRIES

\author{
Meqbel Mishary Aliedan \\ Department of Management, School of Business, King Faisal University, Al-Ahsa, Saudi Arabia \\ E-mail: Maliedan@kfu.edu.sa (Corresponding author)
}

Received 15 November 2019; accepted 10 July 2020; published 30 October 2020

\begin{abstract}
This study examines the impact of overall business climate on the environmental sustainability factor by specifically considering the ASEAN countries named as Philippines, Malaysia, Vietnam and Singapore. This paper fills the gap of the previous researches by majorly considering the trade openness, competitiveness and ease of doing business as independent variables, environmental sustainability as a dependent variable, while GDP and inflation are studied as controlling variables. All the variables data are collected from the country's official sites over the period of 2000-2015. The long-run equilibrium relationship between the tested variables is confirmed by Kao and Pedroni based panel cointegration tests. According to the fully modified ordinary least square (FMOLS) results, the trade openness, ease of doing business, and GDP cause a significant negative influence on the environmental sustainability within the selected states as compared to competitiveness based independent variables. This paper is an informative approach in front of their state's business community, government, policymakers, natives, and other related ones to consider the negative influence of overall business climate on the environment. In addition, there are some limitations like if industrialization and population growth are considered as controlling variables then more significant and authentic outcomes will be generated.
\end{abstract}

Keyword: Trade Openness; Competitiveness; Ease of Doing Business; GDP; Inflation; Environmental Sustainability

Reference to this paper should be made as follows: Aliedan, M. M. 2020. Overall business climate and its impact on environmental sustainability: analyzing evidence from ASEAN countries. Journal of Security and Sustainability Issues, 10(Oct), 291-302. http://doi.org/10.9770/jssi.2020.10.Oct(22)

Jel Codes: O1, O53

\title{
1. Introduction
}

The climate of a business plays a vital role in developing and maintaining sustainability in the environment as it has become an essential part of political life (Amran, Ooi, Wong, \& Hashim, 2016; Ohotina, Lavrinenko, Gladevich, \& Lazdans, 2018; Bernardi, 2019; Pogodina, Aleksakhina, Burenin, Polianova, \& Yunusov, 2019; Al Mazrouei, Khalid, \& Davidson, 2020; Mazzoni, 2020).

The ASEAN countries can develop and find numerous opportunities to develop and according to Rasiah, Ahmed, Al-Amin, and Chenayah (2017) enhance their competitive positioning by innovating products and services in the method of addressing climate change that exploits the demands of climate induce (see Figure 1). 


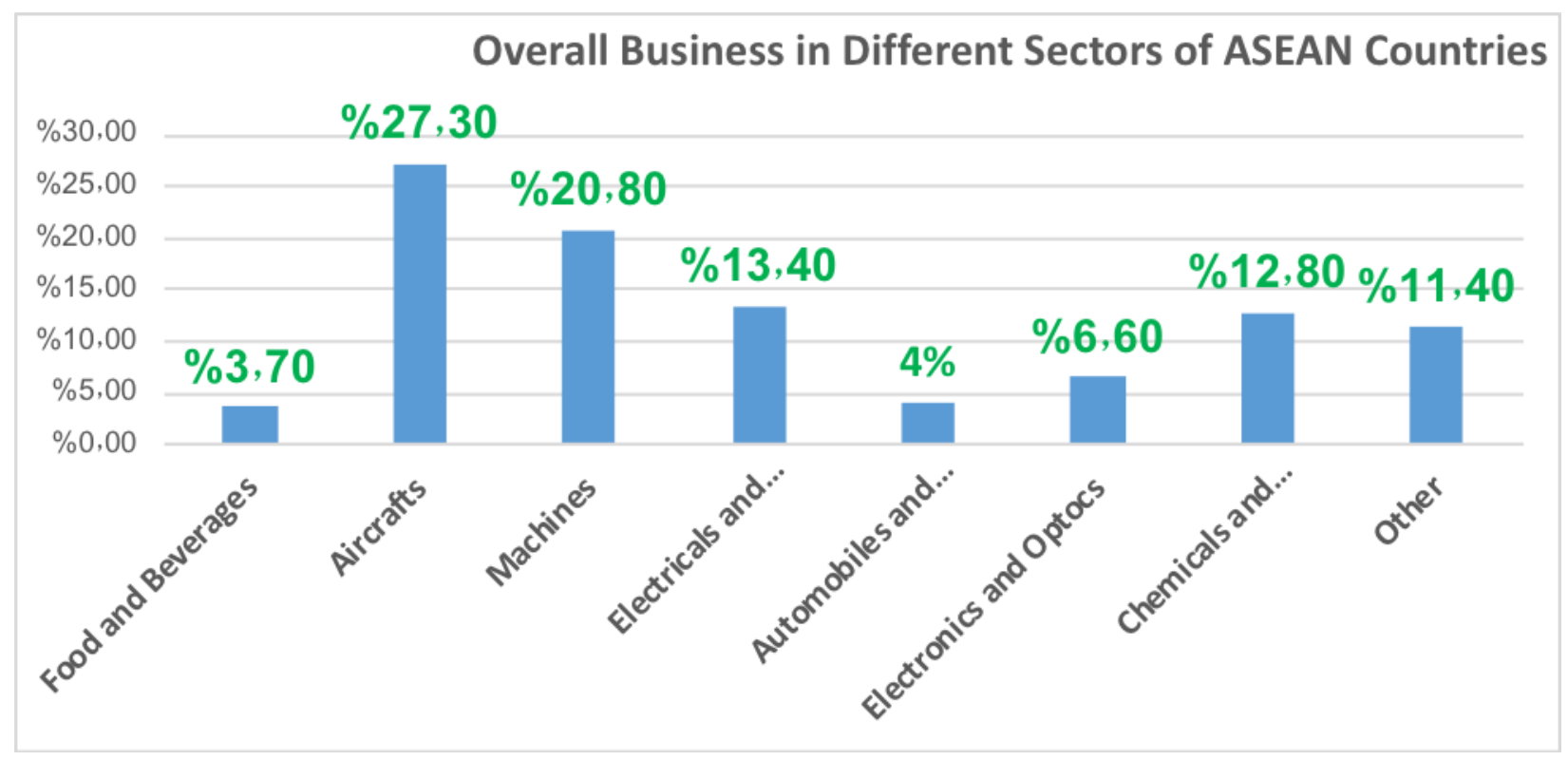

Figure 1: Sector of ASEAN

The climate of business and environmental sustainability (ES) helps in reducing the adverse effect on the business environment (Rasiah, Al-Amin, Chowdhurry, Ahmed, \& Zhang, 2018). ES enables a business to endure prosperity. The ASEAN states are responsible for looking inside out of business to determine and understand the influence of the activities of an organization on its climate. The given enlists some important factors that affect the ES of ASEAN nations (Table 1).

Table 1: Key factors affecting environmental sustainability

\begin{tabular}{ll}
\hline Factors & Description \\
\hline Economic conditions & $\begin{array}{l}\text { External factors that concerned with a business condition such } \\
\text { as trends and competitiveness between ASEAN nations. }\end{array}$ \\
\hline Industrial input & $\begin{array}{l}\text { Factors that consider as an input for business growth and these } \\
\text { factors directly affect ES. }\end{array}$ \\
\hline Supply chain & $\begin{array}{l}\text { The association between suppliers between the supply chain is } \\
\text { reflecting the ES performance. }\end{array}$ \\
\hline
\end{tabular}

There is a lack of enough resources to maintain environmental sustainability in an organization, and strategic planning is not done in the organizations of ASEAN countries that result in sustainability issues. The opportunities regarding the climate of the business are not being offered in ASEAN countries that result in unsustainability in the business environment (Menon \& Melendez, 2017; Sun \& Meng, 2020). Moreover, it also results in decreasing the economic value and productivity of such organizations and can increase their failure rate. There is a lack of CSR activities in the businesses of ASEAN countries as the implementation of CSR activities helps in developing environmental sustainability.

The major purpose of this research is to examine the overall impact of business climate and conditions on the environmental sustainability of ASEAN countries. Although financial development and business activities Vithessonthi and Tongurai (2016) have been examined and evaluated in past efforts and studies, there is a lack of information as well as hypotheses regarding the behavior of different businesses and companies towards environmental sustainability (ES) and other ecological concerns. Therefore, the following paper is remarkable as well as justified largely because no other study in the past has evaluated the overall impact of business dimensions 
and climates such as trade openness and competitiveness. Also, in the past, several scholars such as Osabuohien, Odebiyi, Efobi, and Fayomi (2017) have instantiated the impact as well as the role of business models in affecting the overall environment of the region from different perspectives. Nevertheless, the given project is proving to be very supportive and justified largely because no other past effort has evaluated the impact of business climate such as ease of doing business on the ES of ASEAN countries. The specified study has the following objectives which are,

- The premier objective of the study is to identify the impact of trade openness on environmental sustainability in ASEAN countries.

- The secondary purpose of the research is to examine the impact of competitiveness on environmental sustainability in ASEAN countries.

- And the endmost objective is to evaluate the direct impact of ease of doing business on the environmental sustainability in ASEAN countries.

Businesses that damage the environment generally hide what they are doing to avoid getting caught and also facing social, economic as well as legal results (Dumrul, 2018; Flores \& Rojas, 2020; Tao, 2020). The major aim of the given project is to reveal the insignificant impacts of different businesses on environmental sustainability (ES) level of different ASEAN nations. Therefore, the findings of this paper help business managers to evaluate their business climate to save the environment and ensure ES. Moreover, this research can be executed in almost every type of sector as well as a business operating in ASEAN nations.

The study entails five divisions in which the introduction section describes the scope, significance, problem statement, and the background of the study. The information regarding different types of variables is discussed in the chapter of the literature review. The evidence related to the sample and population size of the research study is defined in the section of the research methodology. The tools and techniques related to the analysis of data are described in the data analysis chapter. The last chapter comprises of conclusion, limitations, implications, and future recommendations.

\section{Literature review}

\subsection{Theory of environmental quality (EQ)}

Quality of environment is one of the world's huge environmental problems Carter, Resh, and Hannaford (2017) and the business climate impact due to contamination and some pollution stretches all around, and according to Nasreen, Anwar, and Ozturk (2017) with certain example pointing to how businesses affect the quality level of the environment which then affects the heath level of individuals. According to this theory heavily polluted regions, majorly have an insignificant time hiring and also retaining employees. According to Charfeddine and Khediri (2016) waste disposal and raw materials is another problem by a different business which affects overall quality of the environment, because according to Le, Chang, and Park (2016) with improper raw materials and disposal mainly resulting in damageable smells which directly affect the air quality of the region. Besides, this theory also states that quality includes the built as well as the natural environment such as water purity, noise, air, pollution, and some other potential impacts which all are directly affected by improper business activities and climates. Furthermore, according to Shahbaz, Shahzad, Ahmad, and Alam (2016) business practices have an insignificant impact on the natural resources which further influence the quality of environments such as oil and timber are utilized to produce goods.

\subsection{The relationship between trade openness and environmental sustainability (ES)}

According to Bernard and Mandal (2016) trade openness (TO) is an indicator of the relative significance of international business in the overall economy of the region. In addition, it is mainly computed by diving aggregate value of the exports as well as imports over a certain period by the GDP at the same time. According to Liu, 
Yuan, Hafeez, and Li (2019) TO majorly be used as a measure of the openness of a region or nation to international business, and therefore may also be referred to as a trade openness ratio. During the past few decades, it comes to the knowledge that openness in business or trade can affect the sustainability of the environment either directly or indirectly to a very significant ratio Shahbaz, Nasreen, Ahmed, and Hammoudeh (2017). How environment-friendly a trade is when it comes to incorporating energy resources and cools the vehicles like ships and trains, to bring goods and products into it, and to eliminate the extra material from it has a direct impact on the level of ES. According to (Mahrinasari, Haseeb, \& Ammar, 2019; Zeb, et al., 2020) vast or open trades between two regions and countries directly affect the quality level of environment, this is mainly because according to Sun, Attuquaye Clottey, Geng, Fang, and Clifford Kofi Amissah (2019) resources that are used during open trade process emit dangerous greenhouse gases which insignificantly affects the ES level of the region. Open trades consume a vast amount of energy resources like diesel, and petrol, even with openness trading recycling waste, according to (Omri, Euchi, Hasaballah, \& Al-Tit, 2019; Iqbal, Adeel \& Khan, 2020) a huge amount of waste and different kinds of disposal still goes to incinerators as well as landfill sites which further affects the ES in an insignificant way. In addition to emissions, openness trade generates a lot of other ecological issues, including types of equipment like modern technologies; this is mainly because according to (Yu, Golpîra, \& Khan, 2018) trading companies regularly modify their trading processes to stay competitive in the market. Additionally, technologies like computers and other devices can majorly end up in landfills where they do not collapse and, according to (Liu, Yuan, Hafeez, \& Yuan, 2018) even damageable, can drain harmful chemicals and materials into the water which finally leads to the direct impact on the level of ES. Hence, the above all discussion leads to the generation of following hypotheses,

H1: There is a positive relationship between trade openness and environmental sustainability.

\subsection{The relationship between competitiveness and environmental sustainability}

Environmental sustainability is considered an essential part of the success of marketplace and corporate strategy as well as the competitiveness strategy of ASEAN countries. According to (DeBoer \& Panwar, 2018) the decisions of a country related to the modalities of environmental conventions or the severity of environmental standards can highly affect the profits of an organization and can make it less competitive in the world vocation. Doyle and Alaniz (2020) describe that when the environmental conventions correlated to sustainability are wisely designed to resolve genuine ecological complications using proficient policy tools, it will not significantly diminish national competitiveness (Hussain et al., 2020). The execution of research related to Chuang and Huang (2018) has revealed that the economy of a country is highly affected by the positive association of environmental sustainability and competitiveness in multiple ways. This relationship can also result in a better and effective outcome if it is related to informal or formal societies that describe property rights and result in the implementation of sustainable processes. Dias (2017) has determined that competitiveness plays an essential role in the contention for the customer base and bigger market share, and it is concerned with the success of an organization. According to Luis, Giulio, and Gabriel (2020), the relationship of competitiveness and environmental sustainability provides a company distinctive external and internal features that assist as strength to preserve its position in this impulsive economy. The researcher Camisón (2020) explains that environmental sustainability in an organization can be enhanced with the help of competitiveness, and the greater value can be provided to the customers along with the greater benefits to the organization. The investigation conducted by Susanto (2019) has articulated that a company needs to maintain its competitiveness along with its environmental sustainability to be successful in this modern economy. The positive relation among sustainable environment and competitive advantage is supported by the theory of environmental quality that the raw materials and water disposal are the problems being faced by a company that affects the quality of its environment badly.

H2: There is a significant association between competitiveness and ES. 
JOURNAL OF SECURITY AND SUSTAINABILITY ISSUES

ISSN 2029-7017/ISSN 2029-7025 (online)

2020 Volume 10 Number (October)

http://doi.org/10.9770/jssi.2020.10.Oct(22)

\subsection{The relationship between the ease of doing business and environmental sustainability}

Ease of doing business (EDB) is a relative concept that has understanding only when the comparison between two regions or states is made Asongu and Odhiambo (2019). A study by (Hassan \& Basit, 2018) manifests that EDB means how easier and effective conditions a country offer to start a business or an enterprise with significant taxation facilities. According to Muli and Aduda (2017), EDB is a concept which means that how easier and supportive facilities a government of a country offer to get an electricity connection for industrial purpose and also access to credit for large business objective (Kamarudin et al., 2020). Besides EDB are supportive conditions that a country offers to foreign investors with extra facilities like relaxation in taxation norms and values, relaxation in GST as well as the property registration laws so that the foreign investors get effective facilities (Jovanovic \& Jovanovic, 2018). According to Vogiatzoglou (2016), ease or facilities in business activities and conditions enlarge the volume as well as the number of enterprises and industries which directly affect the environment and sustainability of environmental efforts. According to ASEAN Environmental Protection Agency, industrial energy use (derive by high facilities in terms of EDB) accounts for about 35\% of total ASEAN greenhouse gas releases. The EDB activities that are major affecting the environment and will continue to affect sustainability and quality in terms of environment and according to Gaur and Jasmin (2017) such challenges as huge emissions, improper waste management, and other business-related issues that affect the environment are generating critical determents. According to (Canton \& Petrucci, 2017) higher demands for energy by industries and business that operate under EDB facilities also translates into more use of natural resources like fossil fuels and water, which then turn into serious environmental issues and affect the sustainability level of the environment. Hence, based on above all discussion this research proposes the below hypotheses,

H3: There is a positive interconnection between the ease of doing business and ES.

\section{Methodology}

In order to explore the influence of overall business climate on the environmental sustainability within the ASEAN states, Indonesia, Thailand, Philippines, Malaysia, Vietnam and Singapore are selected for data evaluation. For data collection, their fifteen years data from 2000 to 2015 are selected from their official sites regarding the major tested variables of this paper. For the above-mentioned proposed hypothesis testing, trade openness, competitiveness and ease of doing business are studied as independent variables, environmental sustainability studied as a dependent variable, while the gross domestic product (GDP) and inflation based variables act as controlling ones between the relationships of two major variables. The relevant data of these tested variables is collected from the previous literature. The following econometric model is specified in order to check the proposed hypothesis, as mentioned in the literature review;

$\mathrm{ENS}=\beta \mathrm{o}+\beta 1 \mathrm{LTRO} i t+\beta 2 \mathrm{LCPN} i t+\beta 3 \mathrm{LEODit}+\beta 3 \mathrm{LGDP} i t+\beta 4 \mathrm{LINF} i t+\varepsilon$ it.

Where LTROit, LCPNit, LEODit, LGDPit, and LINFit are the logarithm forms of trade openness, competitiveness, ease of doing business, environmental sustainability, GDP and inflation.

\subsection{Panel Unit Root Test}

Levin-Lin-Chu (LLU), ADF-Fisher chi-square (ADF-Fisher) and Im, Pesaran and Shin (IPS) based panel unit root tests are implemented to testify the presence of panel stationarity (Cai \& Menegaki, 2019). All these tests have a null hypothesis that there is a unit root in front of any alternative where all variables are stationary. These are represented in the following equation form;

$\mathrm{y} i t=\alpha i+\beta i \mathrm{y} i, t-1+\mathrm{p} i \sum \mathrm{j}=1 \alpha \mathrm{j} \quad \mathrm{yit}-j+e i t \ldots \ldots \ldots \ldots \ldots \ldots(2)$

where, $\triangle y$ it is the difference of $\mathrm{y}$ for the ith country in the time span $\mathrm{t}=1, \ldots \ldots, \mathrm{T}$. This type of statistical test is majorly based on homogeneity assumptions, like Ho: $\beta=\beta i=0$. The heterogeneity is also discussed in equation 2 , by allowing the $\beta i$ to differ across cross-sections like under the alternative hypothesis. Well, some of its tested 
variables may be non-stationary in the test outcomes. The heterogeneous, nonparametric Maddala, Fisher and Wu test based $p$ values in the final panel unit root test is shown in the following equation;

$p=-2 N \sum i=1$ In $\beta i$.

\subsection{Panel Integration Test}

Cointegration test of Pedroni and Kao are majorly considered to test the occurrence of any long term relationship among the variables. The Kao test is a residual and parametric based test to justify no cointegration for the null hypothesis (Sehrawat \& Giri, 2016). It is shown in LSDV regression as shown in the following equation;

$\mathrm{y} i t=\alpha i+\beta \mathrm{Xit}+$ eit

Well, the Dickey-Fuller and its augmented tests are implemented to detect the residuals from the regression equation based estimation. There is a cross-sectional invariant among all the five variations of the Kao test based slope coefficient $(\beta)$ values (Ramenah, Casin, Ba, Benne, \& Tanougast, 2018). In addition, Pendroni based residual cointegration test for no integration of the null hypothesis is implemented for the homogeneity assumption of Kao. Its Pendroni regression equation is discussed below;

$\mathrm{y} i t=\alpha i+\delta i t+\beta i \mathrm{Xit}+e i t$

where $\beta i$, $\delta i$ and $\alpha i$ are free to change across any cross-sections. In the equation 5, two types of statistics based pooling residuals are discussed where the first type pools the obtained residuals on homogeneous panel cointegration statistics based on "within dimension', and the second type pools the obtained residuals along with heterogeneous group mean statistics based on "between dimension".

\subsection{Estimating the Cointegration Relationship with Weighted FMOLS}

Fully Modified Ordinary Least Square (FMOLS) based panel estimation technique is used to estimate the cointegrated panel regression (Pradhan, 2016). It is a nonparametric approach that is helpful to generate an optimal cointegrating regression outcome and designed adjustments for the endogeneity and serial correlation due to the existence of cointegrating relationships. In this paper, Kao and Chiang, and Pedroni specifically pooled the FMOLS estimators for the heterogeneous panels (weighted FMOLS based cointegrated). The relevant asymptotic covariance and estimators are given below;

$\beta^{\wedge} f w=\left(N \sum i=1 T \sum t=1 \mathrm{X} *\right.$ it $\mathrm{X} *$ it $)-1 N \sum i=1 T \sum t=1 \quad(\mathrm{X} *$ it $\mathrm{y} *$ it $-\lambda * 12 i)$

$\mathrm{V} f w=\left(1 / \mathrm{N} \mathrm{N} \sum \mathrm{i}=1\left(1 / \mathrm{T} 2 \mathrm{~T} \sum \mathrm{t}=1 \mathrm{X} * \mathrm{it} \mathrm{X} * \mathrm{it}\right)\right)-1$

\subsection{Cross-Sectional Dependence Test}

Finite and asymptotic sample properties of the panel unit root and the related cointegration tests are implemented in this paper to make an assumption that there is no cross-correlation among the error terms (Dogan, Seker, \& Bulbul, 2017). Also, the relaxation of the cross-sectional dependences based assumptions depicts that the variance-covariance matrix is significantly increased with cross-section number and result in the invalidity of the test distributions. In this paper, the Pesaran CD test is effectively implemented to resolve the size distortion related problems within the test. The pairwise correlation coefficient averages based Pesaran test is implemented to test the null of no cross-sectional dependence and is shown as;

$$
\mathrm{CD} p=(\sqrt{ } 2 / \mathrm{N}(\mathrm{N}-1)) \mathrm{N}-1 \sum \mathrm{i}=1 \mathrm{~N} \sum j=i+1 \mathrm{~T} i j \rho \hat{i} j \rightarrow \mathrm{N}(0,1) \ldots
$$




\section{Analysis Interpretation}

Firstly, the Pesaran cross-sectional dependence (CD) test with the appropriate significance value is implemented. This shows that the tested data do not suffer any cross-correlated error terms, which justified the first-generation models. After this, the unit root test is used to explore the integration order of the tested variables for the precondition panel cointegration tests. According to the following Panel Unit Root test statistics, all the variables are tested in with and without trend, and both in first difference and level. A test results show that the unit root is present at the level and absence of unit roots at the first difference, as shown in the following table 2.

Table 2: Panel Unit Root Test - Im, Pesaran and Shin (IPS)

\begin{tabular}{|c|c|c|c|c|}
\hline Variable & Level & & $1^{\text {st }}$ difference & \\
\hline & Intercept & Intercept + Trend & Intercept & Intercept + Trend \\
\hline TRO & -2.1493 & -2.2933 & $-7.3883 * * *$ & $-7.4771 * *$ \\
\hline $\mathrm{CPN}$ & $-3.2933 *$ & $-3.3994 *$ & $-8.2094 * * *$ & $-8.7564 * *$ \\
\hline EOD & -0.4093 & -1.2094 & $-6.2093 * *$ & $-6.7886 * *$ \\
\hline GDP & $-3.4933 *$ & $-4.4492 * *$ & $-7.4093 * * *$ & $-7.9785 * * *$ \\
\hline INF & $-3.3944 *$ & $-3.389 * *$ & $-7.4844 * * *$ & $-7.5787 * *$ \\
\hline ENS & -2.3984 & $-3.2984 *$ & $-6.4929 * *$ & $-6.8575 * *$ \\
\hline
\end{tabular}

It became confirmed that all the variables are integrated with order one, I(1) where the cointegration test usually proceeds in order to determine the occurrence of a long-run relationship among the independent, dependent and controlling variable. According to the following homogeneous panel cointegration test based Kao and Pedroni cointegration test outcomes, two out of four Pedroni tests are within the dimension-based outcomes (panel ADFstatistics and panel PP-statistic). After this, Kao test depicts that all there is a long-run relationship among the variables. In addition, the heterogeneous cointegration tests are more authentic where two out of three variables are cointegrated. Based on their significant outcome, it becomes concluded that all variables are cointegrated based on the group PP-statistics for both nonparametric and heterogeneous. Specifically, nonparametric tests are more suitable for data which is normally distributed and having more power in Kao and Pedroni tests. Its values are discussed in the following table 3.

Table 3: Cointegration Test - Pedroni Panel

\begin{tabular}{lll}
\hline Test & Statistics & T values \\
\hline (Within Dimension) & & $-32933^{* *}$ \\
Panel $v$-Statistic & -0.573 & $-4.298^{* *}$ \\
Panel $\rho$-Statistic & -0.291 & $-5.2874^{*}$ \\
Panel $t$-Statistic: (non-parametric) & $-2.293^{* *}$ & $-5.9844^{*}$ \\
Panel $t$-Statistic $(a d f):$ (parametric) & $-2.2944^{* *}$ & $-9.93496^{* *}$ \\
(Between Dimension) & & $-3.4044^{*}$ \\
Group $\rho$-Statistic & $-2.9421^{* *}$ & $-3.2944^{*}$ \\
Group $t$-Statistic: (non-parametric) & -0.0372 & $-2.6498^{*}$ \\
Group $t$-Statistic $(a d f):($ parametric) & & \\
\hline
\end{tabular}

After this, the co-efficient of long-run relationship with the FMOLS estimator and its related outcome is shown in the following table. There is a nonparametric estimation technique and is authentic even in the absence of normality assumptions. According to the coefficient outcomes of the tested variables, it becomes clear that trade openness, GDP and ease of doing business are those variables that cause a significant impact on the environmental sustainability factor. Their probability-based significance values also show the same outcomes as their values are lower than the 0.05 standard value. But in case of competitiveness variable, its probability value is appropriate, but its overall outcomes reduce its significant impact on the environmental sustainability factor. In 
JOURNAL OF SECURITY AND SUSTAINABILITY ISSUES

ISSN 2029-7017/ISSN 2029-7025 (online)

2020 Volume 10 Number (October)

http://doi.org/10.9770/jssi.2020.10.Oct(22)

addition, the probability of adjusted $r$ square shows that the significant statistical outcome. Well, inflation is that particular factor whose outcome does not majorly perform in environmental development. The FMOLS estimations are discussed in the following table 4.

Table 4: FMOLS Estimation

\begin{tabular}{llll}
\hline Estimator & Coefficient & Standard Error & Probability \\
\hline TRO & $0.274^{*}$ & 0.568 & 0.000 \\
CPN & 0.034 & 0.856 & 0.007 \\
EOD & $0.201^{*}$ & 0.644 & 0.038 \\
GDP & $0.291^{* *}$ & 0.364 & 0.066 \\
INF & 0.045 & 0.746 & 0.384 \\
Adj. R Square & $\mathbf{0 . 8 9 0}$ & $\mathbf{0 . 8 4 7}$ & $\mathbf{0 . 0 0 0}$ \\
F-Value & $\mathbf{6 6 . 4 8}$ & - & - \\
D.W. Stat & $\mathbf{2 . 2 1}$ & - & - \\
\hline
\end{tabular}

Last, but not the least, the multicollinearity test-based statistical outcomes depict that all the tested values are appropriate. The Variance Inflation Factor (VIF) measures the effect of collinearity among the tested variables in a regression model. Its value is considered as 1/Tolerance where VIF based statistics are greater than 1 which means there is no multicollinearity issue within variables. Its statistical outcomes are given below in table 5 .

Table 5: Multicollinearity Test

\begin{tabular}{lll}
\hline & VIF & 1/VIF \\
\hline TRO & 2.768 & .785 \\
CPL & 1.498 & .788 \\
EOD & 3.479 & .583 \\
GDP & 2.287 & .788 \\
INF & 2.487 & .987 \\
Mean VIF & 1.864 & - \\
\hline
\end{tabular}

\section{Discussion and Conclusion}

\subsection{Discussion}

After critically evaluate the above statistical outcomes, it becomes clear that trade openness and ease of doing business cause a significant negative impact on the environmental sustainability factor due to the excessive existence of GDP based development approach within the selected states. According to Yongmoon, Park with others (2018), trade openness, economic growth, internet use, and financial development cause a direct impact on the carbon dioxide emission in the selected states. According to them, when the FDI and trade activities increased within the states then there will be more chances to boost the negative impact of such development projects on the environmental sustainability factor. Because both economic development and environmental sustainability are inversely proportional to one another (Park, Meng, \& Baloch, 2018). In the energy policy journal, Robi and Shunsuke stated that urbanization and trade openness directly increased the coal consumption that causes a negative impact on the environmental growth. In this case, energy conservation in the residential sector is important to reduce coal consumption (Kurniawan \& Managi, 2018). In this situation, the competition among the companies to earn more profit reduce their motivation to consider the environmental factor in the decision making process that results in the excessive pollution within a developing state and caused an environmental change.

This shows that competition among the companies negatively affects the favorable sustainable environment. In this case, there is a need of an equilibrium solution to maintain the economic competition along with 
JOURNAL OF SECURITY AND SUSTAINABILITY ISSUES

ISSN 2029-7017/ISSN 2029-7025 (online)

2020 Volume 10 Number (October)

http://doi.org/10.9770/jssi.2020.10.Oct(22)

environmental sustainability (Chen, Wang, \& Chan, 2017). The competition of earning more profit and market share within the developing states also boost the concept of ease of doing business by utilizing all the natural resources. In the computers, environment and urban system based journal, Yannis, Vassilis and Catalina critically explored the negative influence of urbanization based ease of doing business concept on the environment sustainability factor that now air, water and land-based natural resources are high jacked by industrialization concept where a large number of companies are struggling to retain their market position. The excessive amount of new businesses increased the greenhouse gas emission and result in global warming issues within the manufacturing industries based developing nations. In a large number of new companies' entry, the inflation rate becomes high and it becomes quite difficult in front of the business community to sustain the healthy environment within their pollution-causing plants (Oláh et al., 2019; Phillis, Kouikoglou, \& Verdugo, 2017).

\section{Conclusion}

Thus, it becomes concluded that there is a significant negative influence of trade openness and ease of doing business on the environmental sustainability factor within Indonesia, Thailand, Philippines, Malaysia, Vietnam and Singapore over the period of 2000-2015. In this case, the GDP based economic indicators played as a major contributor to the emission of carbon dioxide. Well, the competition factor caused a diverse outcome on the environmental sustainability factor because of its indirect effect on the state ecosystem. In order to justify these hypotheses, the unit root test is adopted to testify either variables are integrated into one order or not. In addition, Kao \& Pedroni cointegration tests to check the longterm relationship among variables. After this, the major and important FMOLS test depicted that there is a strong relationship between trade openness, ease of doing business, and GDP on reducing the environmental sustainability factor.

\subsection{Future Implications}

This paper is an informative approach in front of these ASEAN state's administration, the business community, and environmentalists to inspect the overall business climate and its negative influence on their environmental sustainability factor. Its country-wise valid information will also add value in the longterm sustainable environment-oriented business approach and decision-making process by providing proper direction to the policymakers to inspect and evaluate the current situation of this region. In addition, their natives and government can consider their social responsibilities towards the environment after considering this authentic paper. Upcoming scholars in their research studies' discussion can utilize its information.

\subsection{Limitation and Future Researches}

No doubt, it is informative and challenging research but still, there are some deficiencies within its variable selection like if industrialization and population growth based controlling variables are considered for analysis then more authentic and significant outcomes will be generated in its result outcomes. There is an opportunity in front of business researchers to utilize this weakness in their authentic research outcomes. Empirically, other Asian economies, specifically G20 members like Saudi Arabia and Indonesia can be examined within the context of the current research by fellow researchers.

\section{Acknowledgment}

The author extends his appreciation to the Deputyship for Research \& Innovation, Ministry of Education in Saudi Arabia for funding this research work through the project number IFT 20161. 
JOURNAL OF SECURITY AND SUSTAINABILITY ISSUES

ISSN 2029-7017/ISSN 2029-7025 (online)

2020 Volume 10 Number (October)

http://doi.org/10.9770/jssi.2020.10.Oct(22)

\section{References}

Al Mazrouei, M, Khalid, K, \& Davidson, R. (2020). Development and validation of a safety climate scale for United Arab Emirates oil and gas industries to enhance the process safety performance. Entrepreneurship and Sustainability Issues, 7(4), $2863-2882$. http://doi.org/10.9770/jesi.2020.7.4(19)

Amran, A., Ooi, S. K., Wong, C. Y., \& Hashim, F. (2016). Business strategy for climate change: An ASEAN perspective. Corporate Social Responsibility and Environmental Management, 23(4), 213-227.

https://onlinelibrary.wiley.com/doi/abs/10.1002/csr.1371

Asongu, S. A., \& Odhiambo, N. M. (2019). Challenges of doing business in Africa: a systematic review. Journal of African Business, 20(2), 259-268.

https://www.tandfonline.com/doi/abs/10.1080/15228916.2019.1582294

Bernard, J., \& Mandal, S. (2016). The impact of trade openness on environmental quality: an empirical analysis of emerging and developing economies. WIT Trans Ecol Environ, 203, 195-208.

Bernardi, A. 2019. The capability approach and organizational climate as tools to study occupational health and safety, Insights into Regional Development 1(2): 155-169. https://doi.org/10.9770/ird.2019.1.2(6)

Cai, Y., \& Menegaki, A. N. (2019). Convergence of clean energy consumption-panel unit root test with sharp and smooth breaks. Environmental Science and Pollution Research, 26(18), 18790-18803.

Camisón, C. (2020). Competitiveness and Sustainability in Tourist Firms and Destinations: Multidisciplinary Digital Publishing Institute.

https://www.mdpi.com/2071-1050/12/6/2388

Canton, E., \& Petrucci, M. (2017). Ease of doing business in the euro area. Quarterly Report on the Euro Area (QREA), 16(2), 21-29.

Carter, J. L., Resh, V. H., \& Hannaford, M. J. (2017). Macroinvertebrates as biotic indicators of environmental quality Methods in stream ecology (pp. 293-318): Elsevier.

https://www.sciencedirect.com/science/article/pii/B9780128130476000164

Charfeddine, L., \& Khediri, K. B. (2016). Financial development and environmental quality in UAE: Cointegration with structural breaks. Renewable and sustainable energy reviews, 55, 1322-1335.

Chen, X., Wang, X., \& Chan, H. K. (2017). Manufacturer and retailer coordination for environmental and economic competitiveness: A power perspective. Transportation Research Part E: Logistics and Transportation Review, 97, 268-281.

https://www.sciencedirect.com/science/article/pii/S1366554516302721

Chuang, S.-P., \& Huang, S.-J. (2018). The effect of environmental corporate social responsibility on environmental performance and business competitiveness: The mediation of green information technology capital. Journal of business ethics, 150(4), 991-1009.

DeBoer, J. L., \& Panwar, R. (2018). Interdisciplinary Perspectives on the Links between Environmental Governance and Competitiveness: A Systematic Literature Review. Paper presented at the Proceedings of the International Association for Business and Society.

https://philpapers.org/rec/DEBIPO

Dias, J. G. (2017). Environmental sustainability measurement in the Travel \& Tourism Competitiveness Index: An empirical analysis of its reliability. Ecological Indicators, 73, 589-596.

Dogan, E., Seker, F., \& Bulbul, S. (2017). Investigating the impacts of energy consumption, real GDP, tourism and trade on CO2 emissions by accounting for cross-sectional dependence: A panel study of OECD countries. Current Issues in Tourism, 20(16), 1701-1719.

https://www.tandfonline.com/doi/abs/10.1080/13683500.2015.1119103

Doyle, E., \& Alaniz, M. P. (2020). Dichotomous impacts on social and environmental sustainability: competitiveness and development levels matter. Competitiveness Review: An International Business Journal.

Dumrul, Y. (2018). Estimating the Impact of the Financial Development on Energy Consumption: A Co-integration Analysis. International Journal of Energy Economics and Policy, 8(5), 294.

Flores, A., \& Rojas, V. A. C. (2020). Relación entre la demanda de transporte y el crecimiento económico: Análisis dinámico mediante el uso del modelo ARDL. Cuadernos de Economía, 42(122). https://doi.org/10.32826/cude.v42i122.123

Gaur, A. D., \& Jasmin, P. (2017). Ease of Doing Business in India: Challenges \& Road Ahead. Paper presented at the International Conference on Technology and Business Management.

Hassan, Z., \& Basit, A. (2018). Ease of doing business and its impact on inward FDI. Hossain, MT, Hassan, Z., Shafiq, S., \& Basit, A.(2018). Ease of Doing Business and Its Impact on Inward FDI. Indonesian Journal of Management and Business Economics, 1(1), 52-65.

Hussain, H., I., Kot, S., Kamarudin, F., \& Mun, W., C. (2020). The Nexus of Competition Freedom and the Efficiency of Microfinance Institutions. Journal of Competitiveness, 12(2), 67-89. https://doi.org/10.7441/joc.2020.02.05

Iqbal, Z., Adeel, M., \& Khan, M. M. (2020). The effect of leadership styles on employees job satisfaction: a case study on banking sector of pakistan. Hamdard Islamicus, 43(3), 162-174.

Jovanovic, B., \& Jovanovic, B. (2018). Ease of doing business and FDI in the ex-socialist countries. International Economics and Economic Policy, 15(3), 587-627.

https://link.springer.com/article/10.1007/s10368-017-0377-3 


\section{JOURNAL OF SECURITY AND SUSTAINABILITY ISSUES}

ISSN 2029-7017/ISSN 2029-7025 (online)

2020 Volume 10 Number (October)

http://doi.org/10.9770/jssi.2020.10.Oct(22)

Kamarudin, F., Ali, A., Haider, J., Qayyum, A. and Hussain, H. I. (2020) Bank Performance in MENA Region: A Perspective from Bank Efficiency, Risk-Taking Behaviour and Market Competition, Revista Argentina de Clínica Psicológica, 29 (3), 682 - 697. doi: $10.24205 / 03276716.771$

Kurniawan, R., \& Managi, S. (2018). Coal consumption, urbanization, and trade openness linkage in Indonesia. Energy Policy, 121, 576583.

Le, T.-H., Chang, Y., \& Park, D. (2016). Trade openness and environmental quality: International evidence. Energy Policy, 92, 45-55.

https://www.sciencedirect.com/science/article/abs/pii/S0301421516300301

Liu, J., Yuan, C., Hafeez, M., \& Li, X. (2019). ISO 14001 certification in developing countries: motivations from trade and environment. Journal of Environmental Planning and Management, 1-25.

Liu, J., Yuan, C., Hafeez, M., \& Yuan, Q. (2018). The relationship between environment and logistics performance: evidence from Asian countries. Journal of Cleaner Production, 204, 282-291.

https://www.sciencedirect.com/science/article/abs/pii/S0959652618326714

Luìs, G., Giulio, G., \& Gabriel, P. (2020). Environmental innovations, income distribution, international competitiveness and Environmental Policies: a Kaleckian growth model with a balance of payments constraint. Structural Change and Economic Dynamics.

Mahrinasari, M., Haseeb, M., \& Ammar, J. (2019). Is trade liberalization a hazard to sustainable environment?: fresh insight from ASEAN countries. Polish Journal of Management Studies, 19.

http://yadda.icm.edu.pl/yadda/element/bwmeta1.element.baztech-ea98a568-0bfc-48ae-9eac-0295da74c3c5

Mazzoni, F. (2020). Circular economy and eco-innovation in Italian industrial clusters. Best practices from Prato textile cluster. Insights into Regional Development, 2(3), 661-676. https://doi.org/10.9770/IRD.2020.2.3(4)

Menon, J., \& Melendez, A. C. (2017). Realizing an ASEAN Economic Community: Progress and remaining challenge. The Singapore Economic Review, 62(03), 681-702.

Muli, W., \& Aduda, J. (2017). The mediating effect of ease of doing business on the relationship between economic integration and foreign direct investment in the east African community. J Fin Inv Analysis, 6(4), 21-54.

Nasreen, S., Anwar, S., \& Ozturk, I. (2017). Financial stability, energy consumption and environmental quality: Evidence from South Asian economies. Renewable and sustainable energy reviews, 67, 1105-1122.

https://www.sciencedirect.com/science/article/abs/pii/S1364032116305147

Ohotina, A., Lavrinenko, O., Gladevich, J., \& Lazdans, D. (2018). The investment climate in Latvia's, Lithuania's and Belarus's crossborder regions: the subjective-objective assessment, Entrepreneurship and Sustainability Issues 6(2): 767-780. http://doi.org/10.9770/jesi.2018.6.2(20)

Oláh, J., Kitukutha, N., Haddad, H., Pakurár, M., Máté, D., \& Popp, J. (2019). Achieving sustainable e-Commerce in environmental, social and economic dimensions by taking possible trade-offs. Sustainability, 11(1), 89.

https://www.mdpi.com/2071-1050/11/1/89

Omri, A., Euchi, J., Hasaballah, A. H., \& Al-Tit, A. (2019). Determinants of environmental sustainability: Evidence from Saudi Arabia. Science of the Total Environment, 657, 1592-1601.

Osabuohien, E. S., Odebiyi, J. T., Efobi, U. R., \& Fayomi, O. O. (2017). Financial development, trade costs and bilateral trade flows: connecting the nexus in ECOWAS Investment and Competitiveness in Africa (pp. 153-175): Springer.

Park, Y., Meng, F., \& Baloch, M. A. (2018). The effect of ICT, financial development, growth, and trade openness on CO 2 emissions: an empirical analysis. Environmental Science and Pollution Research, 25(30), 30708-30719.

https://link.springer.com/article/10.1007/s11356-018-3108-6

Phillis, Y. A., Kouikoglou, V. S., \& Verdugo, C. (2017). Urban sustainability assessment and ranking of cities. Computers, Environment and Urban Systems, 64, 254-265.

Planas, A., Reig, F., Palmi, J., Del Arco, I., \& Prat, J. A. (2020). Motivations, barriers and physical condition in adolescents, according to the stage of change in physical exercise. Revista de Psicologia del Deporte, 29(2), 125-134.

Pogodina, T.V., Aleksakhina, V.G., Burenin, V.A., Polianova, T.N., \& Yunusov, L.A. (2019). Towards the innovation-focused industry development in a climate of digitalization: the case of Russia, Entrepreneurship and Sustainability Issues 6(4): 1897-1906. http://doi.org/10.9770/jesi.2019.6.4(25)

Pradhan, K. C. (2016). Does remittance drive economic growth in emerging economies: Evidence from FMOLS and Panel VECM. Theoretical \& Applied Economics, 23(4).

Ramenah, H., Casin, P., Ba, M., Benne, M., \& Tanougast, C. (2018). Accurate determination of parameters relationship for photovoltaic power output by augmented dickey fuller test and engle granger method.

Rasiah, R., Ahmed, A., Al-Amin, A. Q., \& Chenayah, S. (2017). Climate change mitigation: comparative assessment of Malaysian and ASEAN scenarios. Environmental Science and Pollution Research, 24(3), 2632-2642.

https://link.springer.com/article/10.1007\%2Fs11356-016-7985-2

Rasiah, R., Al-Amin, A. Q., Chowdhurry, A. H., Ahmed, F., \& Zhang, C. (2018). Climate change mitigation projections for ASEAN. Journal of the Asia Pacific Economy, 23(2), 195-212.

Sehrawat, M., \& Giri, A. (2016). Panel data analysis of financial development, economic growth and rural-urban income inequality. International Journal of Social Economics. 
JOURNAL OF SECURITY AND SUSTAINABILITY ISSUES ISSN 2029-7017/ISSN 2029-7025 (online)

2020 Volume 10 Number (October)

http://doi.org/10.9770/jssi.2020.10.Oct(22)

Shahbaz, M., Nasreen, S., Ahmed, K., \& Hammoudeh, S. (2017). Trade openness-carbon emissions nexus: the importance of turning points of trade openness for country panels. Energy Economics, 61, 221-232.

Shahbaz, M., Shahzad, S. J. H., Ahmad, N., \& Alam, S. (2016). Financial development and environmental quality: the way forward. Energy Policy, 98, 353-364.

https://www.sciencedirect.com/science/article/abs/pii/S0301421516304682

Sun, H., Attuquaye Clottey, S., Geng, Y., Fang, K., \& Clifford Kofi Amissah, J. (2019). Trade openness and carbon emissions: Evidence from belt and road countries. Sustainability, 11(9), 2682.

Susanto, A. B. (2019). The Effect Of Government Policy And Environmental Sustainability On The Performance Of Tourism Business Competitiveness: Empirical Assessment On The Reports Of International Tourism Agencies. International Journal of Energy Economics and Policy, 9(6), 439-446.

Sun, H., \& Meng, Y. (2020). Effects of ideological and political education on mentally unhealthy state of college students after entrepreneurial failure. Revista Argentina de Clinica Psicologica, 29(1), 235-241. https://doi.org/10.24205/03276716.2020.31

Tao, R. (2020). Psychological analysis on appreciators of different styles of art design. Revista Argentina de Clinica Psicologica, 29(1), 385-391. https://doi.org/10.24205/03276716.2020.53

Vithessonthi, C., \& Tongurai, J. (2016). Financial markets development, business cycles, and bank risk in South America. Research in International Business and Finance, 36, 472-484.

Vogiatzoglou, K. (2016). Ease of doing business and FDI inflows in ASEAN. Journal of Southeast Asian Economies, $343-363$.

Yu, Z., Golpîra, H., \& Khan, S. A. R. (2018). The relationship between green supply chain performance, energy demand, economic growth and environmental sustainability: An empirical evidence from developed countries. LogForum, 14(4).

Zeb, N., Iqbal, Z., \& Zeb, A. A. (2020). Impact Of Personality Traits On Investment Decision With Moderating Role Of Financial Literacy. Hamdard Islamicus, 43(3), 153-161.

Meqbel Mishary ALIEDAN, PhD, is an assistant professor at the School of Business, King Faisal University, in Hofuf, Saudi Arabia. He holds a bachelor's degree in Marketing (Honor) from King Faisal University ; a master's degree in International Business (Distinction) from University of Birmingham; and a doctorate degree in International Business \& Strategy from University of Sheffield. His areas of expertise include international business, strategic management, talents development, and Human Resources management. Dr. Aliedan is currently the Dean of Development \& Quality Assurance at King Faisal University and has provided a series of consultations and participated in multiple projects at national \& international levels. He also has different research outputs in the fields of SMEs internationalization, international franchising, internationalization entry modes, dynamic capability of international firms, commercial diplomacy and business research.

ORCID ID: https://orcid.org/0000-0002-2964-7559

This work is licensed under the Creative Commons Attribution International License (CC BY).

http://creativecommons.org/licenses/by/4.0/

CC) (i) Open Access 